\title{
Protease-resistant Form of Insulin-like Growth Factor-binding Protein 5 Is an Inhibitor of Insulin-like Growth Factor-I Actions on Porcine Smooth Muscle Cells in Culture
}

\author{
Yumi Imai, ${ }^{*}$ Walker H. Busby, Jr., ${ }^{*}$ Christine E. Smith, ${ }^{\ddagger}$ Jane B. Clarke, ${ }^{*}$ Aaron J. Garmong, ${ }^{*}$ Gayle D. Horwitz, ${ }^{*}$ \\ Catherine Rees, ${ }^{*}$ and David R. Clemmons* \\ *Department of Medicine, University of North Carolina School of Medicine, Chapel Hill, North Carolina 27599-7170; and \\ ${ }^{\ddagger}$ Searle/Monsanto Inc., St. Louis, Missouri 63196
}

\begin{abstract}
IGFs are pleiotrophic mitogens for porcine smooth muscle cells (pSMC) in culture. The effects of IGFs on cells are modulated by various insulin-like growth factor-binding proteins (IGFBP). IGFBP-5 is synthesized by pSMC and binds to the extracellular matrix. However, IGFBP-5 is also secreted into conditioned medium of cultured cells and is cleaved into fragments by a concomitantly produced protease. These fragments have reduced affinity for the IGFs and cleavage makes it difficult to assess the role of intact IGFBP-5. To study the consequence of accumulation of intact IGFBP-5 in medium, we determined the cleavage site in IGFBP-5 and prepared a protease resistant mutant.

Amino acid sequencing of purified IGFBP-5 fragments suggested $\mathrm{Arg}^{138}{ }_{-} \mathrm{Arg}^{139}$ as the primary cleavage site. $\operatorname{Arg}^{138}$. $\mathrm{Arg}^{139} \rightarrow \mathrm{Asn}^{138}$-Asn ${ }^{139}$ mutations were introduced to create protease-resistant IGFBP-5, which has the same affinity for IGF-I as the native protein. This mutant IGFBP-5 remained intact even after $24 \mathrm{~h}$ of incubation and it inhibited several IGF-I actions when added to pSMC culture medium. The mutant IGFBP-5 (500 $\mathrm{ng} / \mathrm{ml})$ decreased IGF-I stimulated cellular DNA synthesis by $84 \%$, protein synthesis by $77 \%$, and it inhibited IGF-I stimulated migration of pSMC by 77\%. It also inhibited IGF-I stimulation of IRS-1 phosphorylation. In contrast, the same amount of native IGFBP-5 did not inhibit IGF-I actions. The significance of inhibitory effects of the protease resistant IGFBP-5 was further demonstrated in pSMC transfected with mutant or native IGFBP-5 cDNAs. The mutant IGFBP-5 accumulated in culture medium of transfected cells, while native IGFBP-5 was degraded into fragments. PSMC overexpressing the mutant IGFBP-5 also responded poorly to IGF-I compared with mock transfected cells. IGF-I $(5 \mathrm{ng} / \mathrm{ml})$ increased $\left[{ }^{35}\right.$ S]methionine incorporation into control cells by $36 \%$ above the basal level, but it did not significantly change (4\%) in pSMC cultures that were producing the mutant
\end{abstract}

Address correspondence to David R. Clemmons, Chief, Division of Endocrinology, CB \#7170, 6111 Thurston Bowles Bldg., The University of North Carolina at Chapel Hill, Chapel Hill, NC 27599-7170. Phone: 919-966-4735; FAX: 919-966-6025.

Received for publication 14 March 1997 and accepted in revised form 29 August 1997.

J. Clin. Invest.

(C) The American Society for Clinical Investigation, Inc. 0021-9738/97/11/2596/10 \$2.00

Volume 100, Number 10, November 1997, 2596-2605

http://www.jci.org
IGFBP-5. In conclusion, the accumulation of protease-resistant IGFBP-5 in the medium was inhibitory to IGF-I actions on pSMC. This suggests that proteolysis can prevent IGFBP-5 from acting as an inhibitor of IGF-I-stimulated effects and that it serves as an important mechanism for regulating cellular responsiveness to IGF-I. (J. Clin. Invest. 1997. 100:2596-2605.) Key words: Somatomedin-C • serine protease - atherosclerosis $\bullet$ smooth muscle cell migration • IGF-I receptor

\section{Introduction}

IGF-I is a pleotypic mitogen for smooth muscle cells (SMC) ${ }^{1}$ (1). Rat, porcine, and human smooth muscle cells have been shown to respond to IGF-I with increased DNA synthesis (1$3)$, cell growth $(1,3,4)$, cellular migration (5), and protein synthesis (6), as well as increases of specific extracellular matrix (ECM) proteins such as, plasminogen activator inhibitor-1 (7). These cells possess abundant IGF receptors (8) and transfection with antisense oligonucleotides that inhibit receptor synthesis (9) or incubation with anti-IGF-I antisera (10) results in attenuation of their DNA synthesis responses in the basal state and of their responses to growth factors contained in serum (9). Therefore, IGF-I appears to be a potent SMC mitogen when added alone and a potent comitogen for other growth factors as well as an agent that is capable of stimulating extracellular matrix protein secretion. Both processes are thought to be important in establishing and maintaining neointima formation.

In addition to synthesis of IGF-I, these cells also synthesize and secrete three forms of insulin-like growth factor binding proteins (IGFBP-2, IGFBP-4, and IGFBP-5) (11, 12). While substantial concentrations of intact IGFBP-2 are present in smooth muscle cell-conditioned medium, IGFBP-4 and -5 are much less abundant (11). IGFBP-4 has been shown to attenuate the actions of IGF-I (11). IGFBP-2 has been shown to both attenuate (13) and enhance IGF-I actions (14). Although it is a potent inhibitor of smooth muscle cell migration under certain conditions (5), it has been shown to enhance the effects of IGF-I on pSMC DNA synthesis (14). This may be partly due to its ability to bind to proteoglycans in the extracellular matrix when sufficient IGF-I is present in the microenvironment (15).

IGFBP-5 actions on smooth muscle cells have not been studied in detail, however, IGF-I-stimulated DNA synthesis in

1. Abbreviations used in this paper: $\mathrm{CHO}$, Chinese hamster ovary; ECM, extracellular matrix; IGFBP, IGF-binding protein; IRS-1, insulin receptor substrate-1; PI 3-kinase, phosphoinositide 3'-kinase; PPP, platelet-poor plasma; pSMC, porcine smooth muscle cells. 
fibroblasts is enhanced when the concentration of IGFBP-5 in the extracellular matrix is increased (16). Porcine smooth muscle cells (pSMC) synthesize abundant amounts of IGFBP-5, however, no intact IGFBP-5 can be detected in their conditioned medium (11). This is due to the concomitant secretion of an IGFBP-5 protease that cleaves IGFBP-5 into two fragments which have very low affinities for IGF-I. Since the accumulation of IGFBP-5 in the medium in an intact form, as compared with ECM, may result in markedly different effects on IGF-I actions, this protease has the potential to regulate the amount of intact IGFBP-5 in the pericellular environment and thereby modulate IGF-I actions. These studies were undertaken to determine the cleavage site in IGFBP-5 and use in vitro mutagenesis to prepare a protease resistant form of IGFBP-5 to determine the effects of increasing the concentration of intact IGFBP-5 in the conditioned medium on IGF-I actions.

\section{Methods}

Materials. DME was purchased from Lineberger Comprehensive Cancer Center (Chapel Hill, NC). Methionine-free DME, FBS, penicillin, streptomycin, and Geneticine ${ }^{\circledR}$ (G418) were from Gibco BRL (Grand Island, NY). Cohn fraction V BSA, an alkaline phosphataseconjugated goat anti-guinea pig second antibody, poly-L-ornithine, and dimethyl sulphoxide were from Sigma Chemical Co. (St. Louis, MO). IGF-I was a gift from Genentech (South San Francisco, CA). Des(1-3)-IGF-I was a gift from Monsanto, Inc. (St. Louis, MO). $\left[{ }^{3} \mathrm{H}\right]$ thymidine and $\left[{ }^{35} \mathrm{~S}\right]$ methionine were from ICN Biomedical Inc. (Costa Mesa, CA). Hygromycin B was from Calbiochem-Novabiochem International (San Diego, CA). Centricon-10 microconcentrators were from Amicon (Berkeley, MA). Restriction endonucleases were from New England Biolabs, Inc. (Beverly, MA). T4 DNA polymerase and T4 DNA ligase were from Boehringer Mannheim Corp. (Indianapolis, IN). The antibody against human IGFBP-5 was prepared as described previously (17). The antibodies against phosphotyrosine, rat insulin receptor substrate-1 (IRS-1) plekstrin homology domain, and phosphoinositide 3 '-kinase (polyclonal) were purchased from Upstate Biotechnology Inc. (Lake Placid, NY). The oligonucleotides used for mutagenesis were synthesized by the Lineberger Cancer Research Center, Nucleic Acids Core facility (Chapel Hill, NC).

Preparation of IGFBP-5 protease and analysis of IGFBP-5 proteolysis. Approximately 1.2 liters of serum-free conditioned medium that had been obtained from confluent porcine smooth muscle cell cultures was centrifuged at $1200 \mathrm{~g}$ to remove cellular debris and then applied to a heparin sepharose column $(2 \times 4 \mathrm{~cm}$; Pharmacia Biotech, Uppsala, Sweden) that had been equilibrated with $0.5 \mathrm{M}$ Tris, $0.1 \mathrm{M}$ $\mathrm{NaCl}, 2.2 \mathrm{mmol} \mathrm{CaCl}$, $\mathrm{pH}$ 7.2. The sample was loaded at $20 \mathrm{ml} / \mathrm{h}$ and washed with starting buffer until absorbence returned to baseline. The proteins were eluted with step gradients containing the starting buffer plus $0.5 \mathrm{M} \mathrm{NaCl}$ followed by $2.0 \mathrm{M} \mathrm{NaCl}$ in the same buffer. Approximately $10 \mu \mathrm{l}$ of each fraction that had been eluted with $0.5 \mathrm{M}$ $\mathrm{NaCl}$ was incubated with $80 \mathrm{ng}$ of pure human IGFBP-5 for $14 \mathrm{~h}$ at $37^{\circ} \mathrm{C}$ in $60 \mu \mathrm{l}$ of $0.5 \mathrm{M}$ Tris containing $50 \mathrm{mM} \mathrm{NaCl}, 2 \mathrm{mM} \mathrm{CaCl}_{2}, \mathrm{pH}$ 7.2. The reaction products were then analyzed by SDS-PAGE, followed by immunoblotting as described below. The lower limit of sensitivity for detecting IGFBP-5 using this technique is $\sim 0.5 \mathrm{ng}$. The fraction that contains the maximum proteolytic activity toward native IGFBP-5 was used as the source of partially purified IGFBP-5 protease.

Purification of IGFBP-5 fragments after proteolysis. $25 \mu \mathrm{g}$ of native IGFBP-5 or the S143A, K144N IGFBP-5 mutant was incubated with partially purified IGFBP-5 protease for $48 \mathrm{~h}$ at $37^{\circ} \mathrm{C}$ in the buffer listed previously. The reaction mixture was subsequently applied to an IGF-I affinity column that had been equilibrated in $0.05 \mathrm{M}$ sodium phosphate, $\mathrm{pH}$ 6.6, containing $2 \mathrm{mM}$ EDTA and $0.1 \mathrm{M} \mathrm{NaCl}$. After
$16 \mathrm{~h}$ of recirculation, the retained intact IGFBP-5 and IGFBP-5 fragments were eluted with $0.5 \mathrm{M}$ acetic acid. Fractions containing immunoreactive IGFBP-5 and IGFBP-5 fragments were determined by immunoblotting, then loaded onto a reverse phase HPLC C4 column (Vydac, Hespenia, CA) equilibrated with $0.4 \%$ triflouroacetic acid and $\mathrm{H}_{2} \mathrm{O}$. Elution was accomplished with a $0-60 \% \mathrm{CH}_{3} \mathrm{CN}$ gradient over $1 \mathrm{~h}$. The fractions were screened by immunoblotting and those containing IGFBP-5 fragments were concentrated by lyophilization then subjected to amino acid sequence analysis.

Amino acid sequence analysis. Automated Edman degradation chemistry was used to determine the $\mathrm{NH}_{2}$-terminal protein sequence of the fractions containing proteolytic fragments. An Applied Biosystems Inc. model 470 gas-phase sequencer (Foster City, CA) was used for the degradations using the standard sequencer cycle, $0.03 \mathrm{RPTH}$ (18). The sequentially released PTH amino acid derivatives were identified by reverse phase HPLC analysis in an on-line fashion using an Applied Biosystems model 120A PTH Analyzer fitted with a Brownlee 2.1-mm inner diameter PTH C-18 column.

Plasmid construction for expression of native IGFBP-5 and the IGFBP-5 mutants. A full-length human IGFBP-5 cDNA was cloned into the HindIII and NotI sites of a mammalian expression plasmid pRcRSV (pRcRSV-IGFBP-5, [19]). The pRcRSV-IGFBP-5 contains a bacteriophage origin of replication (f1) that allows production of plasmid DNA in a single-stranded form suitable for site-directed mutagenesis. Mutant IGFBP-5 cDNA in pRcRSV were prepared from pRcRSV-IGFBP-5 using a method described previously (19). Briefly, single-stranded phagemid DNA was generated from pRcRSV-hIGFBP-5 and mutations were introduced using synthetic oligonucleotides as substrates for antisense DNA synthesis. The sequence of complementary oligonucleotides used were as follows: ccgacaaaattggcctgggtca, Ser ${ }^{143}$ to Ala, and Lys ${ }^{144}$ to Asn (S143A, K144N-IGFBP5); actgggtcagattatttctggcgtc, Lys $^{138}$ to Asn, and Lys $^{139}$ to Asn (K138N, K139N-IGFBP-5). Plasmids thus created were sequenced, and the clones containing the correct sequences were amplified and purified using silica gel anion exchange resin chromatography (Qiagen, Chatsworth, MA).

Transfection of Chinese hamster ovary (CHO) cells. CHO (K1) cells were obtained from Lineberger Comprehensive Cancer Tissue Culture facility. Cells were maintained in alpha essential medium, $10 \%$ FBS supplemented with penicillin $(100 \mathrm{U} / \mathrm{ml}) /$ streptomycin $(100$ $\mu \mathrm{g} / \mathrm{ml}$ ). Cells were transfected with pRcRSV-hIGFBP-5 (native and mutants) using calcium phosphate precipitation procedure and the positive clones were selected with $800 \mu \mathrm{g} / \mathrm{ml}$ of $\mathrm{G} 418$ as described previously (19).

Purification of native IGFBP-5 and IGFBP-5 mutants. Conditioned medium of $\mathrm{CHO}$ cells overexpressing IGFBP-5 (native and mutants) was centrifuged at 10,000 $g$ for $20 \mathrm{~min}$ to remove cellular debris. Each recombinant IGFBP-5 was then purified as described (16). The amount of each mutant was quantified by comparing their HPLC peak areas to an IGFBP-5 standard. The concentration of the pure IGFBP- 5 standard had been determined by amino acid composition analysis (16). To determine that each mutant had no change in its affinity for IGFBP-5, Scatchard analysis was performed as previously described. Briefly, ${ }^{125}$ I-IGF-I (20,000 cpm per tube) was incubated with $2 \mathrm{ng} / \mathrm{ml}$ of native or IGFBP-5 mutant in $0.25 \mathrm{ml}$ of $0.1 \mathrm{M}$ Hepes, $0.1 \%$ BSA, $\mathrm{pH}$ 6.0. Duplicate tubes were incubated with increasing concentrations of IGF-I, $0.053-1.33 \mathrm{nM}$. Bound and free IGF-I were separated by precipitation using $12 \%$ polyethylene glycol (Mw 8,000$12,000)$ as described previously $(20)$. The data were then analyzed according to the method of Scatchard and the results that were obtained with native IGFBP-5 were compared to those obtained using each mutant.

Incubation of recombinant native or mutant IGFBP-5 with porcine smooth muscle cells. Porcine aortic smooth muscle cells (pSMC) were isolated from thoracic aorta of newborn pigs (age $3 \mathrm{wk}$ ) (21) and maintained in DME supplemented with $10 \%$ FBS, $100 \mathrm{U} / \mathrm{ml}$ penicillin, and $100 \mu \mathrm{g} / \mathrm{ml}$ streptomycin as described previously (22). The cells were plated at a density of $2.5 \times 10^{4}$ per $\mathrm{cm}^{2}$ in 96 -well culture 
plates (Falcon ${ }^{\circledR}$; Becton Dickinson and Co., Franklin Lakes, NJ) and grown for $5 \mathrm{~d}$ to confluence. Cultures were rinsed once with DME without FBS then native IGFBP-5 or the IGFBP-5 mutants (500 ng/ $\mathrm{ml}$ ) were added in $0.1 \mathrm{ml} /$ well DME supplemented with $0.2 \%$ human platelet-poor plasma (PPP) (23). The incubation was continued for $24 \mathrm{~h}$. Culture media thus prepared were analyzed by immunoblotting as described below.

Immunoblotting. The 24-h conditioned medium obtained from the pSMC cultures was mixed with four times Laemmli sample buffer (in case of media incubated with purified IGFBP-5) or after concentrating fivefold by ultrafiltration through a Centricon-10 microconcentrator (in case of media obtained from IGFBP- 5 overexpressing cells). The mixture was then incubated at $65^{\circ} \mathrm{C}$ for $10 \mathrm{~min}$. Between $20-40 \mu \mathrm{l}$ of each sample was separated on a $12.5 \%$ SDS polyacrylamide gel using a Mighty Small II gel apparatus (Hoeffer Scientific Instruments, San Francisco, CA). After electrophoresis, the separated proteins were transferred onto PVDF membrane (Immobilon-P, $0.45-\mu \mathrm{m}$ pore size; Millipore Corp., Bedford, MA) as described previously (22). The membrane was probed using 1:1,000 dilution of polyclonal guinea pig antiserum against human IGFBP-5 and visualized with an alkaline phosphatase-conjugated goat anti-guinea pig second antibody as described previously (24).

Measurement of $\left[{ }^{3} \mathrm{H}\right]$ thymidine incorporation into porcine smooth muscle cells. PSMC were plated at a density of $2.5 \times 10^{4}$ per $\mathrm{cm}^{2}$ in 96-well culture plates and grown for $5 \mathrm{~d}$ without change of culture medium. Cultures were rinsed once with DME without FBS, and incubated in $100 \mu \mathrm{l} /$ well DME supplemented with $0.2 \%$ PPP for $24 \mathrm{~h}$ in the presence of $0.5 \mu \mathrm{Ci} /$ well [ ${ }^{3} \mathrm{H}$ ]thymidine (sp act, $35 \mathrm{Ci} / \mathrm{mmol}$ ), IGF-I $(0$ or $20 \mathrm{ng} / \mathrm{ml})$, and various concentrations of IGFBP-5 $(0-500 \mathrm{ng} / \mathrm{ml})$. In some experiments, $20 \mathrm{ng} / \mathrm{ml}$ des(1-3)-IGF-I was used instead of IGF-I. At the end of incubation, the plates were placed on ice, washed with ice-cold phosphate-buffered saline twice, and incubated with ice-cold $5 \%$ TCA for $10 \mathrm{~min}$. TCA precipitates thus formed were solubilized by adding $0.1 \mathrm{ml}$ of $1 \%$ SDS, $0.1 \mathrm{~N} \mathrm{NaOH}$ overnight, and radioactivity was measured with a Beckman scintillation counter using ScintiSafe ${ }^{\mathrm{TM}}$ Econo 2 (Fischer Scientific, Fair Lawn, NJ) as a scintillant.

Measurement of ${ }^{35}$ S/methionine incorporation into porcine smooth muscle cells. PSMC were grown to subconfluence on 24-well culture plates. Cultures were rinsed once with serum-free DME, and incubated with $0.25 \mathrm{ml}$ of low methionine DME (a mixture of $10 \%$ DME and $90 \%$ methionine-free DME) for $24 \mathrm{~h}$ in the presence of $0.05 \mu \mathrm{Ci} /$ well $\left[{ }^{35} \mathrm{~S}\right]$ methionine (specific activity, $1,206 \mathrm{Ci} / \mathrm{mmol}$ ), IGF-I ( 0 or 20 $\mathrm{ng} / \mathrm{ml}$ ), and various concentrations of IGFBP-5 (0 to $500 \mathrm{ng} / \mathrm{ml})$. After the incubation, the amount of ${ }^{35} \mathrm{~S}$ that had been incorporated into the cells was determined using the same extraction method as for measuring $\left[{ }^{3} \mathrm{H}\right]$ thymidine incorporation.

Cell migration assay. PSMC were grown to confluence on 6-well culture plates. The confluent monolayers were wounded with a single razed blade as described by Jones et al. (25). The plate was rinsed once and incubated in DME plus $0.2 \%$ FBS with IGF-I ( 0 or $100 \mathrm{ng}$ / $\mathrm{ml})$ and IGFBP-5 (0 to $500 \mathrm{ng} / \mathrm{ml})$ for $2 \mathrm{~d}$ at $37^{\circ} \mathrm{C}$. After the incubation, the number of cells migrating across the wound area was determined. Each data point represents a mean of 7-10,1-mm regions that were selected immediately after wounding.

Immunoprecipitation. PSMC were grown to subconfluence on 100-mm culture dishes. Cells were washed three times with serumfree DME and incubated with DME plus $0.1 \%$ BSA for $24 \mathrm{~h}$. IGFBP-5 was added to the conditioned medium to a final concentration of $500 \mathrm{ng} / \mathrm{ml}$ and the incubation was continued for an additional $24 \mathrm{~h}$. IGF-I ( 0 or $50 \mathrm{ng} / \mathrm{ml}$ ) was added to the conditioned medium and the cells were stimulated for $10 \mathrm{~min}$. The cultures were solubilized in 0.5 $\mathrm{ml}$ of lysis buffer ( $1 \%$ Nonidet P-40; $0.25 \%$ sodium deoxycholate; $1 \mathrm{mM}$ EGTA; $150 \mathrm{mM} \mathrm{NaCl} ; 50 \mathrm{mM}$ Hepes $\mathrm{pH}$ 7.5; $100 \mathrm{mM}$ sodium fluoride; $10 \mathrm{mM}$ sodium pyrophosphate; $2 \mathrm{mM}$ sodium vanadate; 0.3 $\mu \mathrm{g} / \mathrm{ml}$ PMSF; $1 \mu \mathrm{g} / \mathrm{ml}$ pepstatin A; $1 \mu \mathrm{g} / \mathrm{ml}$ leupeptin). The insoluble material was removed by centrifugation at $13,000 \mathrm{~g}$ for $10 \mathrm{~min}$ and the supernatant was incubated with $2 \mu \mathrm{g}$ of anti-IRS-1 antibody over- night at $4^{\circ} \mathrm{C}$. The immune complexes were incubated with protein-A Sepharose (Sigma Chemical Co.) at $4^{\circ} \mathrm{C}$ for $2 \mathrm{~h}$. The immobilized protein A was sedimented by centrifugation at 7,000 $\mathrm{g}$ for $1 \mathrm{~min}$, washed four times with lysis buffer, and the proteins were resuspended in Laemmli sample buffer. The samples were separated on SDS-PAGE and transferred to a PVDF membrane as described above. The membrane was incubated with a 1:1,000 dilution of antiphosphotyrosine antibody or anti PI 3-kinase antibody. The immune complexes were visualized by incubating with enhanced chemiluminescence (SuperSignal CL-H substrate system; Pierce, Rockford, IL) and exposing to Kodak X-AR film (Eastman Kodak Co., Rochester, NY).

Transfection of porcine smooth muscle cells with native and mutant IGFBP-5 cDNA. For the transfection of pSMC, the native and mutant IGFBP-5 cDNAs were subcloned from the pRcRSV expression plasmid into the pMEP4 expression plasmid (Invitrogen Corp., San Diego, CA). pRcRSV containing the native IGFBP-5, S143A, K144N-IGFBP-5, or K138N, K139N-IGFBP-5 inserts were digested with XbaI, and the ends were filled in with T4 DNA polymerase. The cDNAs were released from plasmids by KpnI digestion and ligated into the pMEP4 expression plasmid using $50 \mathrm{ng}$ of pMEP4 DNA, 50 $\mathrm{ng}$ of each insert, and T4 DNA ligase (1.5 U). The pMEP4 plasmid had been prepared with XhoI and T4 DNA polymerase to contain a $3^{\prime}$ blunt end, and with $\mathrm{KpnI}$ to contain a $5^{\prime} \mathrm{KpnI}$ overhanging end. The ligation mixture was used to transform XBLT competent Escherichia coli (Stratagene Cloning System, La Jolla, CA) and the clone that contained the correct insert was amplified and purified as described above.

PSMC were seeded on 6-well tissue culture plates $(3.5 \mathrm{~cm})$ and grown to $80 \%$ confluence. Plasmid DNA was introduced into cells by poly-L-ornithine method (26). On the day of transfection, mixture of $1.5 \mu \mathrm{g}$ plasmid DNA, $1 \%$ FBS, and $3 \mu \mathrm{g}$ poly-L-ornithine was prepared in $0.3 \mathrm{ml}$ of DME and added to each well. The plates were then incubated for $6 \mathrm{~h}$ at $37^{\circ} \mathrm{C}$. This treatment was removed and replaced with $0.3 \mathrm{ml}$ of DME containing $25 \%$ DMSO plus $2 \%$ FBS for 4 min at room temperature. After rinsing twice, cells were incubated in DME with $10 \% \mathrm{FBS}$ at $37^{\circ} \mathrm{C}$ for $48 \mathrm{~h}$ with one medium change at $24 \mathrm{~h}$. The treated cells were trypsinized, plated on three $10-\mathrm{cm}$ plates then grown in DME plus $10 \%$ FBS with $100 \mu \mathrm{g} / \mathrm{ml}$ hygromycin B. Fresh medium containing $100 \mu \mathrm{g} / \mathrm{ml}$ hygromycin B was applied every 3-4 d until cells reached subconfluence $(\sim 3 \mathrm{wk})$. Medium was analyzed for secretion of IGFBP-5 by immunoblotting. $1 \mu \mathrm{l}$ of culture medium was directly applied to a nitrocellulose membrane. The membrane was dried, probed using 1:1,000 dilution of polyclonal guinea pig antiserum against human IGFBP-5, and visualized with an alkaline phosphatase-conjugated goat anti-guinea pig second antibody as described previously (24). The sensitivity of detection was adjusted such that the IGFBP-5 that was endogenously secreted by nontransfected or mock transfected porcine smooth muscle cells could not be detected. The plates that produced detectable amounts of IGFBP-5 were maintained in DME with $50 \mu \mathrm{g} / \mathrm{ml}$ hygromycin B. The culture media were also analyzed by $12.5 \%$ SDS-PAGE with immunoblotting. The positive plates were washed once with serum-free DME and incubated for $24 \mathrm{~h}$ in DME plus $0.1 \%$ BSA with or without $100 \mu \mathrm{g} / \mathrm{ml}$ heparin. The conditioned media were then concentrated five times by ultrafiltration through a Centricon-10 microconcentrator and analyzed by immunoblotting as described above.

Measurement of $\left[{ }^{3} \mathrm{H}\right]$ thymidine incorporation into porcine smooth muscle cells overexpressing native and mutant IGFBP-5. Porcine smooth muscle cells that had been stably transfected with native and $\mathrm{K} 138 \mathrm{~N}$, K139N-IGFBP-5 cDNAs were plated at a density of $2.5 \times 10^{4}$ per $\mathrm{cm}^{2}$ in 96-well culture plates and grown till confluence (usually $7 \mathrm{~d}$ ). PSMC transfected with pMEP4 vector without IGFBP-5 cDNA (mock transfection) were also prepared as control. Cultures were rinsed once with DME without FBS, and incubated in $100 \mu \mathrm{l} /$ well DME supplemented with $0.2 \%$ PPP for $24 \mathrm{~h}$ to allow the IGFBP-5 that was secreted by transfected cells to accumulate. At this time, 0.5 $\mu \mathrm{Ci} /$ well $\left[{ }^{3} \mathrm{H}\right]$ thymidine (sp act, $\left.35 \mathrm{Ci} / \mathrm{mmol}\right)$ plus IGF-I $(0-20 \mathrm{ng} / \mathrm{ml})$ was added to each well, and incubation was continued for additional 
$24 \mathrm{~h}$ at $37^{\circ} \mathrm{C}$. After total of $48 \mathrm{~h}$ incubation, $\left[{ }^{3} \mathrm{H}\right]$ thymidine incorporation into cells was determined as described previously.

Measurement of $\left[{ }^{35} S /\right.$ methionine incorporation into porcine smooth muscle cells overexpressing native and mutant IGFBP-5. PSMC stably transfected with native IGFBP-5, or the mutant IGFBP-5 cDNAs were plated at a density of $2.0 \times 10^{4}$ per $\mathrm{cm}^{2}$ in 24-well and grown to subconfluence (usually $5 \mathrm{~d}$ ). Mock transfected cells were also used as control. Cultures were rinsed once with serum-free DME and incubated in $250 \mu \mathrm{l} /$ well of low methionine DME (20\% DME and $80 \%$ of methionine-free DME) plus $0.01 \%$ BSA for $24 \mathrm{~h}$. At that time, 0.05 $\mu \mathrm{Ci} /$ well $\left[{ }^{35} \mathrm{~S}\right]$ methionine (sp act, $\left.1,206 \mathrm{Ci} / \mathrm{mmol}\right)$ plus IGF-I (0-20 ng/ $\mathrm{ml}$ ) was added to each well, and the incubation was continued for additional $24 \mathrm{~h}$ at $37^{\circ} \mathrm{C}$. The amount of ${ }^{35} \mathrm{~S}$ that had been incorporated into the cells was quantified as for $\left[{ }^{3} \mathrm{H}\right]$ thymidine (see above).

Statistical analysis. Student's $t$ test was used to compare difference between the control and the test groups.

\section{Results}

Determination of the proteolytic cleavage site in IGFBP-5 by the protease that is secreted by porcine smooth muscle cells. PSMC cultures secrete a protease that has characteristics of a serine protease activity based on protease inhibitor activity profiles (27). Therefore, it was believed that basic residues were most likely the sites of cleavage. Analysis of partially purified proteolytic fragment by SDS-PAGE consistently yielded a predominant 22-kD fragment. Amino terminal sequencing of this fragment showed that it contained the amino terminal sequence of the intact protein. However, when the peptides that adhered to the IGF-I affinity column were sequenced an easily discernible sequence beginning with lysine 144 was detected. This experiment was repeated three times with the same result which suggested that the $22-\mathrm{kD}$ fragment was generated by cleavage at the $\operatorname{Ser}^{143}$, Lys ${ }^{144}$ position. To confirm that this was the primary cleavage site, a mutant containing the substitutions S143N, K144N was prepared and its susceptibility to proteolysis was determined. Although this protein was relatively resistant to cleavage compared to native IGFBP-5, prolonged incubation times clearly resulted in proteolytic cleavage (Fig.

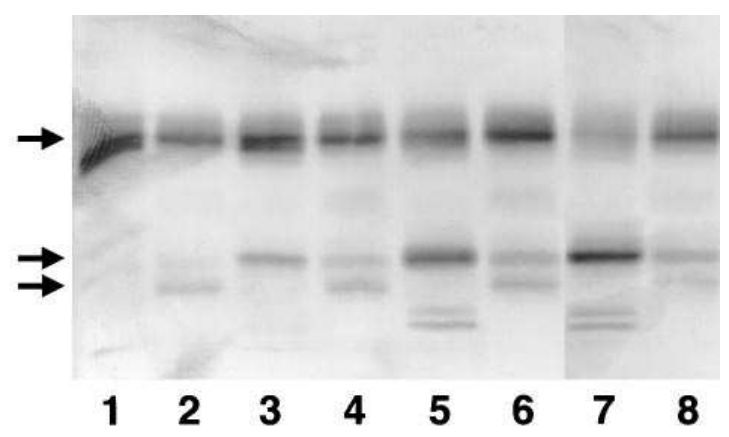

Figure 1. Cleavage of native IGFBP-5 and S143N, K144N-IGFBP-5 by the smooth muscle cell protease. Partially purified IGFBP-5 protease from pig smooth muscle cell conditioned medium was incubated with $59 \mathrm{ng} / \mathrm{ml}$ of native IGFBP-5 (lanes 1,3,5, and 7) or S143N, K144N-IGFBP-5 (lanes 2, 4, 6, and 8) for various time periods. After its incubation, the products of the reaction were analyzed by immunoblotting. The upper arrow denotes the molecular weight estimate of intact IGFBP-5 and the next arrow denotes the position of the major 22-kD fragment (lanes 1 and 2, $1 \mathrm{~h}$; lanes 3 and $4,4 \mathrm{~h}$; lanes 5 and $6,8 \mathrm{~h}$; lanes 7 and $8,14 \mathrm{~h}$ ).

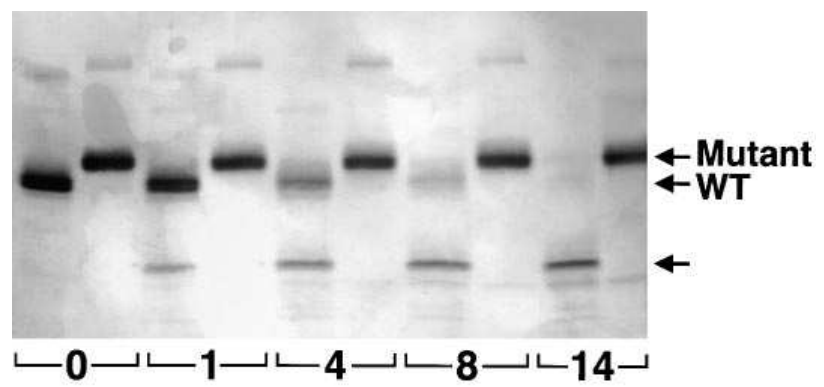

Figure 2. Degradation of native IGFBP-5 and K138N, K139NIGFBP- 5 by pSMC protease. The partially purified protease was incubated with native IGFBP-5 $50 \mathrm{ng}$ or K138N, K139N-IGFBP-5 $50 \mathrm{ng}$ for time periods between 0 and $14 \mathrm{~h}$. Products of the reaction were analyzed by immunoblotting. The upper arrow denotes the migratory position of the IGFBP-5 mutant shown in lanes 2, 4, 6, 8, and 10 and native IGFBP-5 shown in lanes 1,3,5, 7, and 9. The lower arrows shows the position of the 22-kD fragment (lanes 1 and $2,0 \mathrm{~h}$; lanes 3 and $4,1 \mathrm{~h}$; lanes 5 and $6,4 \mathrm{~h}$; lanes 7 and $8,8 \mathrm{~h}$; lanes 9 and $10,14 \mathrm{~h}$ ).

1). Incubation for $72 \mathrm{~h}$ resulted in cleavage that was nearly complete, therefore, the rate of the cleavage of this mutant was attenuated, but not abolished.

To determine the location of cleavage site in this mutant, the purified S143N, K144N mutant was incubated with the protease. The resulting fragments were purified and then sequenced. Again, the $\mathrm{NH}_{2}$-terminus of the protein was detected when the most abundant fragment was sequenced. However, a second fragment beginning with lysine 139 as the amino terminal amino acid was also detected, and additional sequencing of this fragment showed that the S143N, K144N mutation was present. This suggested that K138, K139 could be the primary cleavage site in the protein and that subsequent cleavage by an amino peptidase might account for the appearance of the S143, K144 cleavage site that had been detected previously. To determine if K138, K139 was the primary cleavage site, this site was mutated to K138N, K139N. Incubation of this mutant with the partially purified IGFBP-5 protease for periods up to $72 \mathrm{~h}$ resulted in no detectable proteolytic cleavage (Fig. 2). Although the band migrated somewhat aberrantly on the gel, there was almost no fragment detectable in this preparation after the prolonged incubation. In contrast, the S143N, K144N mutant was nearly totally degraded over this time period and the native IGFBP-5 was totally degraded. Thus, it appeared that K138, K139 was the primary cleavage site and the fragment that contained K144 as the amino terminal amino acid was probably generated due to further degradation after the primary cleavage reaction. Therefore, the K138N, K139N mutant was used to determine the effect of attenuating IGFBP-5 proteolysis on IGF-I action.

To determine if these amino acid substitutions had altered the affinity of K138N, K139N IGFBP-5 for IGF-I, solution binding assays and Scatchard analysis were performed. The association constant $\left(K_{\mathrm{a}}\right)$ of K138N, K139N-IGFBP-5 was $1.9 \times$ $10^{9} \mathrm{M}^{-1}$ which was comparable to affinity of native IGFBP-5 (e.g., $2.2 \times 10^{9} \mathrm{M}^{-1}$ ). This mutant has been shown to have a 2.1-fold reduction in its affinity for extracellular matrix (our unpublished observation).

The purified mutant IGFBP-5 incubated with porcine smooth muscle cells in culture is resistant to proteolysis. Native 


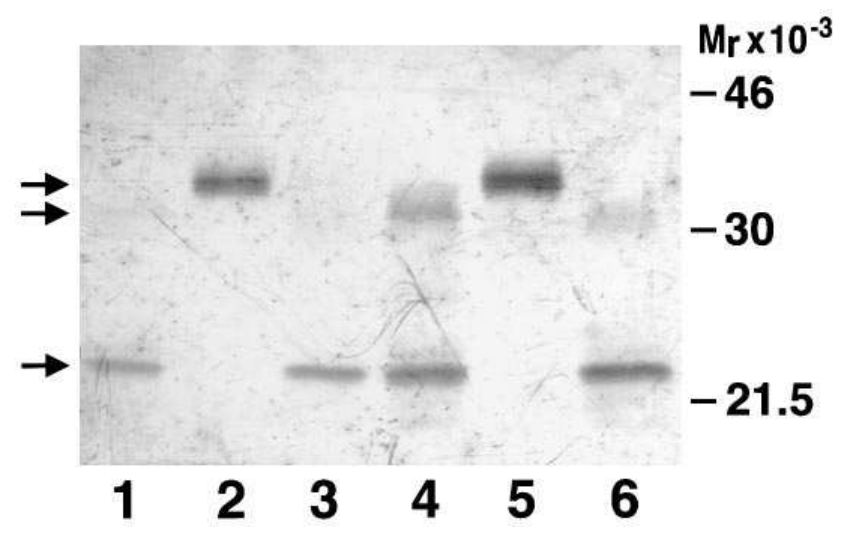

Figure 3. Immunoblot analysis of purified native IGFBP-5, S143N, K144N-IGFBP-5, and K138N, K139N-IGFBP-5 after incubation with porcine smooth muscle cell cultures. Native-IGFBP-5, S143N, K144N-IGFBP-5, and K138N, K139N-IGFBP-5 purified as described were added to culture media of pSMC at the concentration of $500 \mathrm{ng} /$ $\mathrm{ml}$ in the absence (lane 1,2, and 3), or in the presence of $20 \mathrm{ng} / \mathrm{ml}$ IGF-I (lane 4, 5, and 6). The cells were then incubated for $24 \mathrm{~h}$ at $37^{\circ} \mathrm{C}$ and $30 \mu \mathrm{l}$ of the media were collected and analyzed by SDSPAGE with immunoblotting using the human IGFBP-5 antibody. The arrows denote intact IGFBP-5 and the 22-kD fragment. Lane 1 and 4, S143N, K144N-IGFBP-5; lane 2 and 5, K138N, K139N-IGFBP-5; lane 3 and 6, native-IGFBP-5. The figure is representative of the results of six independent experiments.

IGFBP-5, S143N, K144N-IGFBP-5, and K138N, K139NIGFBP-5 were added to the culture media of $\mathrm{pSMC}$ at concentrations of $500 \mathrm{ng} / \mathrm{ml}$ for $24 \mathrm{~h}$. Media were collected, separated on $12.5 \%$ SDS-PAGE and analyzed by immunoblotting. Native IGFBP-5 incubated without IGF-I was completely degraded into a $22-\mathrm{kD}$ fragment, and the addition of IGF-I protected native IGFBP-5 from proteolysis to some extent as had been demonstrated previously (Fig. 3) (17). S143N, K144NIGFBP-5 was partially resistant to proteolysis compared with native IGFBP-5 (Fig. 3). In contrast, K138N, K139N IGFBP-5 did not yield any fragments (Fig. 3) and only the intact form was detected after $24 \mathrm{~h}$ incubation. This further supported the conclusion that K138, K139 is the primary site of cleavage by the IGFBP-5 protease secreted by pSMC.

Purified K138N, K139N IGFBP-5 added to culture medium inhibits IGF-I actions on porcine smooth muscle cells. PSMC cultures were incubated with $\left[{ }^{3} \mathrm{H}\right]$ thymidine for $24 \mathrm{~h}$ in the presence of IGF-I and increasing concentrations of native IGFBP-5 or the IGFBP-5 mutants. IGF-I $(20 \mathrm{ng} / \mathrm{ml})$ stimulated the incorporation of $\left[{ }^{3} \mathrm{H}\right]$ thymidine into porcine smooth muscle cells by $50 \%$ above the basal level. The addition of native IGFBP-5 or S143N, K144N-IGFBP-5 at concentrations as high as $500 \mathrm{ng} / \mathrm{ml}$ in culture media did not have any reproducible effects on IGF-I stimulation (Fig. 4). However, addition of $500 \mathrm{ng} / \mathrm{ml}$ of K138N, K139N IGFBP-5 resulted in nearly complete inhibition of the mitogenic effects of IGF-I (Fig. 4). Analysis of the medium at the end of the incubation period showed that most of the added K138N, K139N IGFBP-5 was intact, whereas native IGFBP-5 and S143N, K144N-IGFBP-5 were degraded (Fig. 3). K138N, K139N-IGFBP-5 also decreased $\left[{ }^{3} \mathrm{H}\right]$ thymidine incorporation into pSMC in the absence of added IGF-I. Concentrations of 100 and $500 \mathrm{ng} / \mathrm{ml} \mathrm{de-}$ creased this response by $19.9 \pm 4.9 \%(\times \pm$ S.D., $n=4)$ and $33 \pm 9.5 \%$ compared with cells that were incubated in DME and $0.2 \%$ PPP only. This inhibition is much less than for the cultures that had been stimulated by IGF-I and may be explained by sequestration of IGF-I that is constitutively produced by pSMC during the incubation (10).

To determine if the inhibition of $\left[{ }^{3} \mathrm{H}\right]$ thymidine incorporation by K138N, K139N-IGFBP5 was due to sequestration of IGF-I by the mutant protein, $\left[{ }^{3} \mathrm{H}\right]$ thymidine incorporation into pSMC was stimulated by incubation with des(1-3)-IGF-I, since it has low affinity for IGFBPs. des(1-3)-IGF-I $(20 \mathrm{ng} / \mathrm{ml})$ increased $\left[{ }^{3} \mathrm{H}\right]$ thymidine incorporation into pSMC by $66 \%$ above the basal level. In contrast to inhibition of native IGF-I stimulated $\left[{ }^{3} \mathrm{H}\right]$ thymidine incorporation $\mathrm{K} 138 \mathrm{~N}$, K139NIGFBP-5 did not decrease $\left[{ }^{3} \mathrm{H}\right]$ thymidine incorporation stimulated by des(1-3)-IGF-I significantly (Fig. 5). The data strongly suggest that sequestration of IGF-I to K138N, K139N-IGFBP-5 is primarily responsible for the inhibition observed by the protease resistant IGFBP-5.

The effects of adding native IGFBP-5 or the IGFBP-5 mutants on $\left[{ }^{35} \mathrm{~S}\right]$ methionine incorporation into protein by pSMC were also determined. IGF-I $(20 \mathrm{ng} / \mathrm{ml})$ increased incorporation of $\left[{ }^{35}\right.$ S]methionine into pSMC by $80 \%$. Addition of native IGFBP-5 using concentrations as high as $500 \mathrm{ng} / \mathrm{ml}$ did not significantly decrease the effect of IGF-I (Fig. $6 A$ ). However, K138N, K139N IGFBP-5 addition inhibited the anabolic effect of IGF-I in a dose-dependent manner, and almost complete inhibition was noted when $500 \mathrm{ng} / \mathrm{ml}$ was added (Fig. 6 A). K138N, K139N-IGFBP-5 had no effect on the basal $\left[{ }^{35}\right.$ S]me-

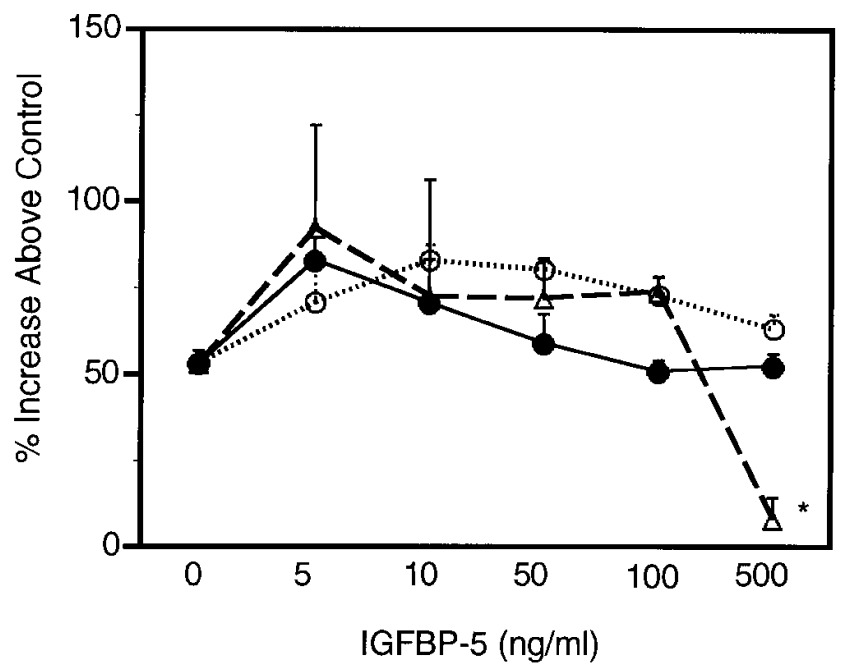

Figure 4. Effects of purified native-IGFBP-5, S143N, K144N-IGFBP-5, and K138N, K139N-IGFBP-5 on IGF-I stimulated $\left[{ }^{3} \mathrm{H}\right]$ thymidine incorporation into porcine smooth muscle cells. PSMC cultures were incubated with $\left[{ }^{3} \mathrm{H}\right]$ thymidine for $24 \mathrm{~h}$ in media that contained $20 \mathrm{ng} / \mathrm{ml}$ IGF-I plus different concentrations of purified native-IGFBP-5 (•), S143N, K144N-IGFBP-5 (O), or K138N, K139N-IGFBP-5 $(\triangle)$. The amount of ${ }^{3} \mathrm{H}$-activity incorporated into cells was measured as described in Methods. The results were expressed as a percentage of increase over control cultures that were incubated with DME plus $0.2 \%$ PPP but no IGF-I or IGFBP- 5 was added. Each value is mean \pm SEM of triplicates. $* P<0.05$ when $500 \mathrm{ng} / \mathrm{ml}$ of native-IGFBP- 5 is compared with $500 \mathrm{ng} / \mathrm{ml}$ of K138N, K139N-IGFBP-5. The figure represents the results of three independent experiments. 


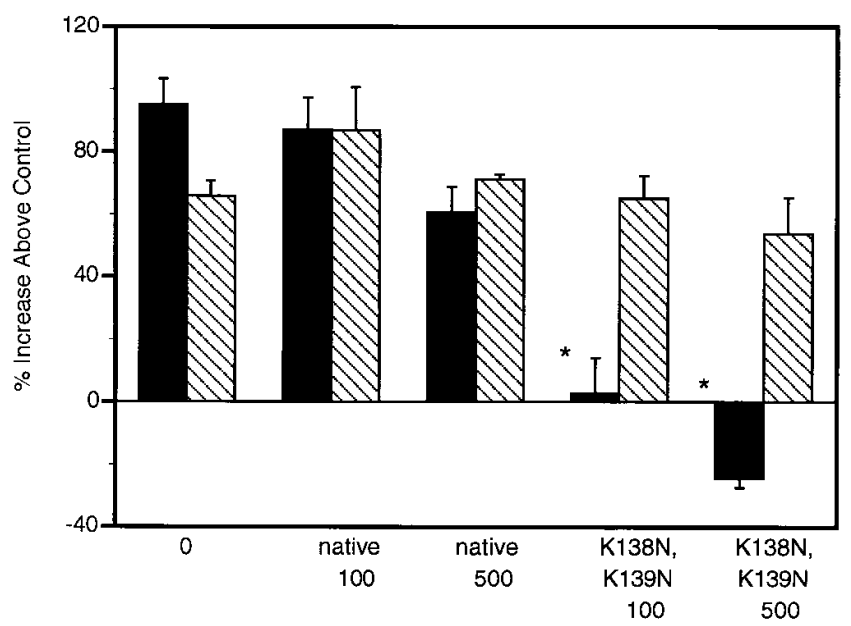

IGFBP-5 (ng/ml) actions of IGF-I and inhibition occurred at a step proximal to IRS-1 phosphorylation. This is consistent with the hypothesis that the mutant IGFBP-5 inhibited IGF-I action by sequestrating it.

Constitutively expressed K138N,K139N-IGFBP-5 in porcine smooth muscle cells accumulates in culture medium without being degraded. PSMC were stably transfected with native IGFBP-5 or K138N, K139N-IGFBP-5 cDNAs. PSMC transfected with pMEP4 expression vector without IGFBP-5 cDNA (mock transfection) were also prepared as control. Transfected cells were incubated for $24 \mathrm{~h}$ in DME with $0.1 \%$ BSA in the presence or absence of $100 \mu \mathrm{g} / \mathrm{ml}$ heparin (added to inhibit the IGFBP-5 proteolysis [24]). Culture media were collected, concentrated, and analyzed by immunoblotting. As is shown in Fig. 8, mock-transfected cells accumulated only $22 \mathrm{kD}$ fragment of IGFBP-5 after $24 \mathrm{~h}$ incubation due to proteolysis and the addition of $100 \mu \mathrm{g} / \mathrm{ml}$ heparin partially inhibited proteoly-

Figure 5. Effects of purified native-IGFBP-5 and K138N, K139NIGFBP-5 on des(1-3)-IGF-I-stimulated $\left[{ }^{3} \mathrm{H}\right]$ thymidine incorporation into porcine smooth muscle cells. PSMC cultures were incubated with $\left[{ }^{3} \mathrm{H}\right]$ thymidine for $24 \mathrm{~h}$ in media that contained $20 \mathrm{ng} / \mathrm{ml}$ of IGF-I (solid bar) or des(1-3)-IGF-I (hatched bar) plus IGFBP-5 (0, 100, or $500 \mathrm{ng} / \mathrm{ml})$. The amount of ${ }^{3} \mathrm{H}$ incorporated into DNA was measured as described in Methods. The results were expressed as a percentage of increase over control cultures that were incubated with DME plus $0.2 \%$ PPP but no IGF-I or IGFBP-5 was added. Each value is mean \pm SEM of triplicates from three separate experiments. $* P<0.05$ when value for the $20 \mathrm{ng} / \mathrm{ml}$ IGF-I plus IGFBP-5 was compared with that for $20 \mathrm{ng} / \mathrm{ml}$ IGF-I only.

thionine incorporation into cells measured in the absence of IGF-I (Fig. 6 B). Thus, the protease-resistant mutant IGFBP-5 inhibited both mitogenic action and anabolic actions of IGF-I presumably by sequestrating IGF-I and preventing binding to IGF-I receptors.

Purified K138N, K139N IGFBP-5 added to culture medium inhibits IGF-I stimulated migration of porcine smooth muscle cells. The addition of $100 \mathrm{ng} / \mathrm{ml}$ of IGF-I resulted in a $166 \pm 9 \%$ increase in cell migration over $48 \mathrm{~h}$. Co-incubation with $100 \mathrm{ng} / \mathrm{ml}$ of $\mathrm{K} 138 \mathrm{~N}$, K139N-IGFBP-5 resulted in a $38 \pm 4 \%$ inhibition of the maximum response and co-incubation of $500 \mathrm{ng} / \mathrm{ml}$ of this IGFBP-5 mutant inhibited maximally stimulated migration by $76 \pm 6 \%(P<0.05)$. In contrast, native IGFBP-5 $(500 \mathrm{ng} / \mathrm{ml})$ in the same experiment resulted in $16 \pm 2 \%$ (NS) inhibition of migration, indicating that the mutant IGFBP-5 was a much more potent inhibitor of IGF-I action (the values are mean \pm SEM of three replicate experiments, each of which consists of 7-10 observation points).

Purified K138N, K139N-IGFBP-5 added to culture medium inhibits IGF-I-stimulated phosphorylation of IRS-1 and its association with PI 3-kinase. Immunoprecipitation of IRS-1 from lysate of pSMC that were stimulated with IGF-I showed that IGF-I increased both phosphorylation of IRS-1 and its association with PI 3-kinase (Fig. 7). The addition of K138N, K139N-IGFBP-5 to the culture medium diminished both IGF-I stimulated phosphorylation of IRS-1 and its association with PI 3-kinase (Fig. 7). In contrast, the cultures incubated with native IGFBP-5 responded normally to IGF-I (Fig. 7). Therefore, K138N, K139N-IGFBP-5 was also inhibitory to short-term

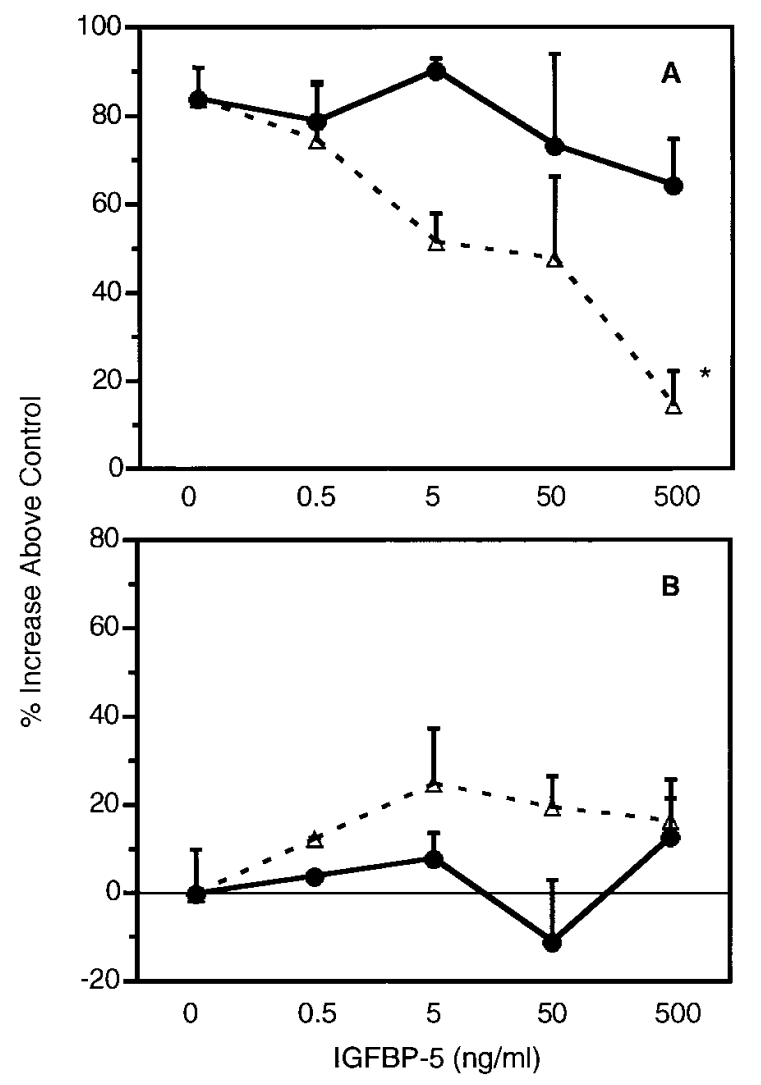

Figure 6. Effects of purified native IGFBP-5 and K138N, K139NIGFBP-5 on IGF-I stimulated $\left.{ }^{35} \mathrm{~S}\right]$ methionine incorporation into porcine smooth muscle cells. PSMC cultures were metabolically labeled with $\left[{ }^{35} S\right]$ methionine for $24 \mathrm{~h}$ in medium that contained $20 \mathrm{ng} / \mathrm{ml}$ IGF-I $(A)$ or no IGF-I $(B)$ plus different concentrations of purified native IGFBP-5 $(\bullet)$ or K138N, K139N-IGFBP-5 $(\triangle)$. The amount of ${ }^{35} \mathrm{~S}$-activity incorporated into cells was measured as described in Methods. The results were expressed as a percentage of increase over control cultures that were incubated in serum-free DME without IGF-1 or IGFBP-5. Each value is mean \pm SEM of triplicates. $* P<$ 0.05 when adding $500 \mathrm{ng} / \mathrm{ml}$ of K138N, K139N-IGFBP-5 and compared with cultures containing the same concentration of native IGFBP-5. The figure represents the results of three independent experiments. 


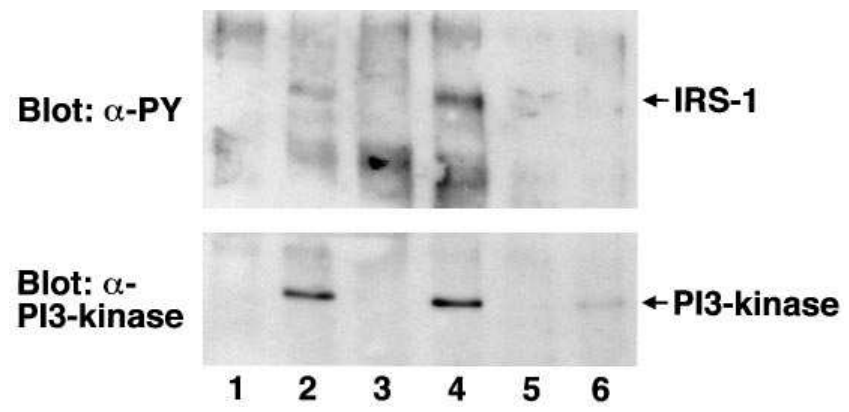

Figure 7. Effects of purified native IGFBP-5 and K138N, K139NIGFBP-5 on IGF-I stimulated phosphorylation of IRS-1 and its association with PI 3-kinase in porcine smooth muscle cells. Subconfluent pSMC were incubated without IGFBP-5 (lane 1 and 2), or with

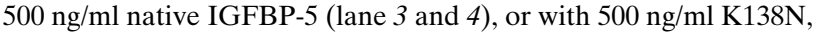
K139N-IGFBP-5 (lane 5 and 6 ) for $24 \mathrm{~h}$. Cells were then treated with $0 \mathrm{ng} / \mathrm{ml} \mathrm{IGF-I} \mathrm{(lane} \mathrm{1,3} \mathrm{and} \mathrm{5)} \mathrm{or} 50 \mathrm{ng} / \mathrm{ml}$ IGF-I (lane 2, 4, and 6) for $10 \mathrm{~min}$. Proteins immunoprecipitated with anti-IRS-1 antibody were separated on $7 \%$ SDS-polyacrylamide gel and transferred to a PVDF membrane. The membrane was blotted with antibody against phosphotyrosine $(\alpha-P Y)$ or PI 3-kinase ( $\alpha$-PI 3-kinase) as described in Methods. The amount of IRS-1 in each lane was confirmed to be similar by blotting with $\alpha$-IRS- 1 antibody. The blot is a representative result of three experiments.

sis. Cells overexpressing native IGFBP-5 also accumulated only the fragment when incubated without heparin, demonstrating the transfected cultures also released the IGFBP-5 protease. When these cells were incubated with heparin, they accumulated more intact form of native IGFBP-5 than mocktransfected cells, confirming that transfected cells were producing more native IGFBP-5 than control cells. Cells overexpressing K138N, K139N-IGFBP-5 accumulated intact IGFBP-5 in the absence of heparin and incubation with heparin did not increase the amount of the intact mutant protein. Therefore, when K138N, K139N-IGFBP-5 is overexpressed in pSMC, it is resistant to the protease that is produced constitutively by the same cell type. Based on the immunoreactive band intensity, the amount of K138N, K139N-IGFBP-5 produced by transfected cells was estimated to be between 30 to $50 \mathrm{ng} / \mathrm{ml}$ per $24 \mathrm{~h}$.

Overexpression of K138N, K139N-IGFBP-5 inhibits the pSMC response to IGF-I. The effect of IGF-I on protein synthesis in the pSMC that were overexpressing K138N, K139NIGFBP-5 was studied by measuring $\left[{ }^{35} \mathrm{~S}\right]$ methionine incorporation. IGF-I stimulated $\left[{ }^{35} \mathrm{~S}\right]$ methionine incorporation into mock-transfected cells in a dose-dependent manner (Fig. 9) that was similar to nontransfected pSMC, suggesting that transfection procedure itself did not alter the sensitivity of pSMC to IGF-I action. IGF-I concentrations $>5 \mathrm{ng} / \mathrm{ml}$ achieved statistically significant increases in $\left[{ }^{35} \mathrm{~S}\right]$ methionine incorporation. In contrast, $5 \mathrm{ng} / \mathrm{ml}$ of IGF-I had no effect on $\left[{ }^{35}\right.$ S]methionine incorporation into cells that overexpressed K138N, K139N-IGFBP-5 (Fig. 9) and it required $20 \mathrm{ng} / \mathrm{ml}$ IGF-I to demonstrate significant stimulation in the cultures that were expressing the mutant protein. In addition, the extent of stimulation at $20 \mathrm{ng} / \mathrm{ml}$ was less than for the mocktransfected cells. Therefore, cells overexpressing K138N, K139N-IGFBP-5 were less responsive to IGF-I. This observa- tion was confirmed by comparing multiple clones of $\mathrm{K} 138 \mathrm{~N}$, K139N-IGFBP-5 overexpressing cells to mock-transfected cells. The IGF-I response observed using the K138N, K139NIGFBP-5 overexpressing cultures is similar to the response obtained when nontransfected pSMC were incubated with purified K138N, K139N-IGFBP-5 (Fig. 6 A). The amount of K138N, K139N IGFBP-5 produced by transfected cells (30 to $50 \mathrm{ng} / \mathrm{ml} 24 \mathrm{~h}$ ) would be expected to block the effect of $5 \mathrm{ng} / \mathrm{ml}$ IGF-I, since $500 \mathrm{ng} / \mathrm{ml}$ of purified K138N, K139N-IGFBP-5 inhibited the action of $20 \mathrm{ng} / \mathrm{ml}$ IGF-I. Although not significantly different from the mock-transfected cells, the IGF-I response in native IGFBP-5 overexpressing cells tended to be slightly less than mock transfected cells (Fig. $6 \mathrm{~A}$ ), suggesting that native IGFBP-5 might be having an inhibitory effect, but that it was degraded too rapidly to sequester an amount of IGF-I that was comparable to the amount in the K138N, K139N-IGFBP-5-expressing cultures. The $\left[{ }^{3} \mathrm{H}\right]$ thymidine incorporation response to IGF-I stimulation was also decreased in pSMC overexpressing K138N, K139N-IGFBP-5 compared with mock transfected cells. IGF-I $(5 \mathrm{ng} / \mathrm{ml})$ increased $\left.{ }^{3} \mathrm{H}\right]$ thymidine incorporation into mock-transfected cells $63 \%$ above the basal level, however it stimulated only $18.6 \%$ increase in K138N, K139N-IGFBP-5 overexpressing cells $(P<0.05$ compared with the response of the mock-transfected cells, $n=5$ ). Therefore, the pSMC overexpressing the protease resistant IGFBP-5 were also less responsive to the mitogenic action of IGF-I.

\section{Discussion}

IGFBP-5 that is secreted into the culture medium of pSMC is actively degraded by a serine protease that is specific for IGFBP-5 (27). The IGFBP-5 protease is a calcium-dependent

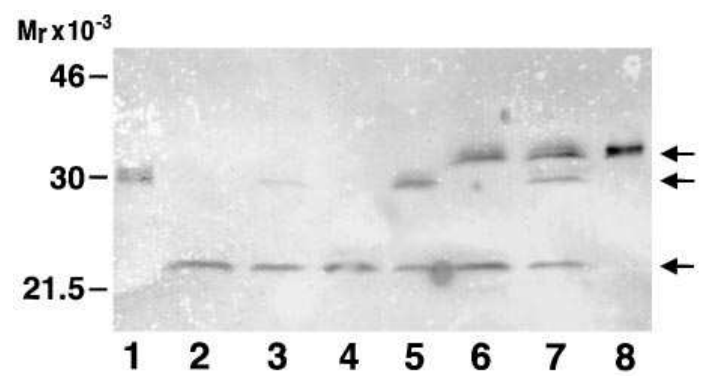

Figure 8. Immunoblot analysis of conditioned medium from porcine smooth muscle cell cultures overexpressing native IGFBP-5 or K138N, K139N-IGFBP-5. pSMC stably overexpressing native IGFBP-5, K138N, K139N-IGFBP-5 or empty vector without cDNA (mock transfection) were grown to subconfluence on $10-\mathrm{cm}$ plates. Cultures were then incubated in DME plus $0.1 \%$ BSA with (lanes 3, 5 , and 7) or without (lanes 2, 4, and 6) $100 \mu \mathrm{g} / \mathrm{ml}$ heparin for $24 \mathrm{~h}$. The condition media thus prepared were concentrated five times using Centricon-10, run on $12.5 \%$ SDS-PAGE, and analyzed by immunoblotting with human IGFBP-5 antibody as described in Methods. The arrows denote intact IGFBP-5 and the $22-\mathrm{kD}$ fragment. Lane 1, purified native-IGFBP-5, $10 \mathrm{ng}$; lanes 2 and 3, condition media from mock transfected cells; lanes 4 and 5 , conditioned media from native IGFBP-5 overexpressing cells; lanes 6 and 7, conditioned media from K138N, K139N-IGFBP-5 overexpressing cells; lane 8, purified K138N, K139N-IGFBP-5, $10 \mathrm{ng}$. The figure represents the results of three independent experiments. 


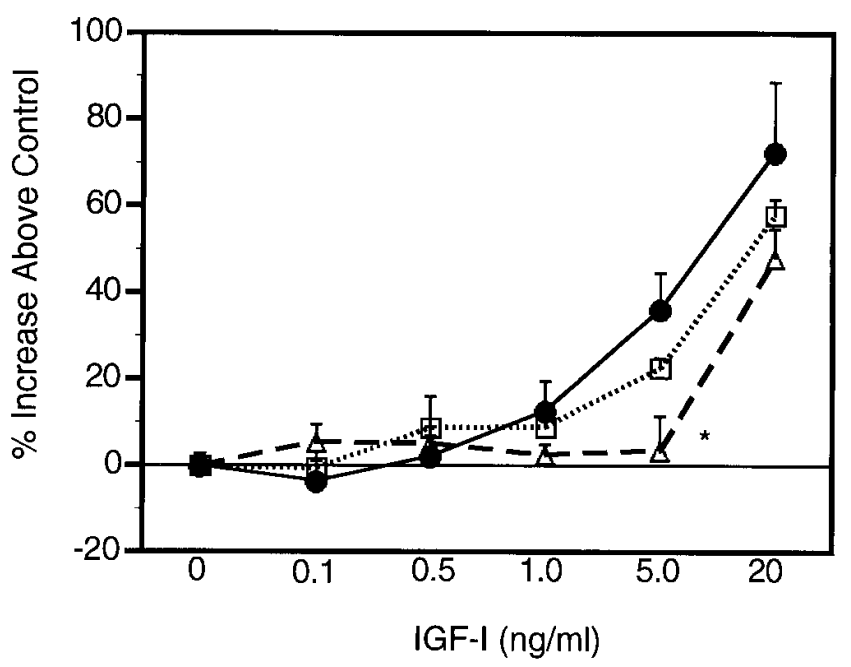

Figure 9. IGF-I stimulated ${ }^{[35}$ S]methionine incorporation into porcine smooth muscle cells overexpressing K138N, K139N-IGFBP-5. Porcine smooth muscle cells stably overexpressing native-IGFBP-5 $(\square)$, K138N, K139N-IGFBP-5 $(\triangle)$, or that had been transfected with an empty vector without a cDNA insert (mock transfection, $\bullet$ ) were grown to subconfluence on 24-well culture plates. The cultures were incubated in low methionine DME containing $0.01 \%$ BSA for $24 \mathrm{~h}$, and then incubated additional $24 \mathrm{~h}$ with different concentrations of IGF-I and $0.05 \mu \mathrm{Ci} /$ well of $\left[{ }^{35} \mathrm{~S}\right]$ methionine. The amount of ${ }^{35} \mathrm{~S}$-activity incorporated into protein was measured as described in Methods. For each experiment, the results were expressed as a percentage of increase over control cultures of individual cell line (mock, native, or $\mathrm{K} 138 \mathrm{~N}, \mathrm{~K} 139 \mathrm{~N}$ ) that were incubated in low methionine DME plus $0.01 \%$ BSA without IGF-I. Each data point is mean \pm SEM of three independent experiments that each contained triplicate determinations. $* P<0.05$ when the mock-transfected cells are compared to the K138N, K139N-IGFBP-5 overexpressing cells. The basal mean values of $\left[{ }^{35} \mathrm{~S}\right]$ methionine incorporated into the cultures were $10,598 \mathrm{cpm}$ (mock transfected), 5,987 cpm (native IGFBP-5), and 13,280 cpm (K138N, K139N IGFBP-5).

serine protease, therefore, it would be expected to cleave dibasic residues within substrate proteins (27). In the present study, we have identified K138, K139 as the primary site cleaved by the IGFBP-5 specific protease. Amino acid sequence analysis of fragments derived from native IGFBP-5 initially suggested S143, K144 as the primary cleavage site. Although the rate of degradation of S143N, K144N-IGFBP-5 was decreased, a fragment was detected after prolonged incubation with the protease. Amino acid sequencing of this fragment showed that K139 was the amino terminus, therefore we hypothesized that $\mathrm{K} 138$, $\mathrm{K} 139$ is the primary cleavage site and the fragment that contained K144 as its amino terminus was generated by further degradation that followed the primary cleavage reaction. This hypothesis was tested by preparing the K138N, K139N mutant and determining its susceptibility to cleavage. The mutant IGFBP-5 showed complete resistance to proteolysis when it was incubated with the partially purified protease in vitro. Similarly, when it was incubated with pSMC cultures, or when overexpressed in pSMC it also remained resistant to cleavage. These observations strongly support that the dibasic residues K138, K139 form the primary cleavage site targeted by this protease.

The mutant K138N, K139N-IGFBP-5 had a somewhat slower electrophoretic mobility on SDS-PAGE compared with native IGFBP-5 indicating that the mutant might have slightly different conformation. However, we do not believe that this change is responsible for the resistance of K138N, K139N IGFBP-5 for two reasons. First, the conformational change in mutant IGFBP-5 did not result in an alteration in its affinity for IGF-I. Second, K139 was found to be the amino terminus of the major proteolytic fragment that was obtained when S143N, K144N-IGFBP5 was used as a substrate. Taken together, these results suggest that K138, K139 is the primary cleavage site in IGFBP-5 and that altering its sequence by substituting neutral amino acids for charged residues results in resistance to proteolysis.

When $500 \mathrm{ng} / \mathrm{ml}$ of native IGFBP-5 was incubated with the pSMC cultures it was completely degraded after $24 \mathrm{~h}$ and did not alter IGF-I stimulation of $\left[{ }^{3} \mathrm{H}\right]$ thymidine incorporation, $\left[{ }^{35} \mathrm{~S}\right]$ methionine incorporation, or cell migration. This suggests that intact IGFBP-5 was not present for a sufficient period of time to inhibit IGF-I-IGF-I receptor interaction. Other investigators have reported that the 22-kD fragment of IGFBP-5 may have direct mitogenic actions for osteoblasts in culture (28). However, we were unable to demonstrate any effect on the pSMC cultures when native IGFBP-5 was added alone and the $22-\mathrm{kD}$ fragment concentration was thereby increased. This difference could be cell type specific or concentration dependent since we added less IGFBP-5 than had been used previously (28).

In contrast to native IGFBP-5, K138N, K139N-IGFBP-5 remained in an intact form in culture medium and inhibited many known actions of IGF-I on pSMC. However, K138N, K139N-IGFBP-5 was not effective in inhibiting $\left[{ }^{3} \mathrm{H}\right]$ thymidine incorporation that was stimulated by des(1-3) IGF-I, an IGF analog that has reduced affinity for IGFBP-5 suggesting this inhibitory effect is most likely due to the sequestration of IGF-I, thereby reducing its availability to bind to receptors. Although some inhibition was noted when a 1:1 molar ratio of IGFBP5/IGF-I was used, a molar excess of IGFBP-5 (3 7:1) was required to significantly block the actions of IGF-I (e.g., $17 \mathrm{nM}$, IGFBP-5 was necessary to maximally block the effect of 2.6 nM IGF-I). A similar molar excess of IGFBP to IGF-I has been reported to be required for sequestration of IGF-I in other test systems (13, 29-33). K138N, K139N-IGFBP-5 also decreased $\left[{ }^{3} \mathrm{H}\right]$ thymidine incorporation into pSMC in the absence of IGF-I by $34 \%$. This suppression could be explained by sequestration of endogenous IGF-I produced during the assay period. These cells have been shown to synthesize IGF-I and the extent of inhibition of basal $\left[{ }^{3} \mathrm{H}\right]$ thymidine incorporation by the protease resistant IGFBP-5 was similar to the decrease in $\left[{ }^{3} \mathrm{H}\right]$ thymidine incorporation into pSMC that can be detected when pSMC are exposed to the anti-IGF-I antibody, SM 1.2 (10). This antibody has also been shown to inhibit the SMC response to PDGF presumably through IGF-I sequestration (10). When we tested the effect of K138N, K139N-IGFBP-5 on PDGF stimulated pSMC cultures, it inhibited $\left[{ }^{3} \mathrm{H}\right]$ thymidine incorporation but it was not as effective as it was when added to IGF-I-stimulated cultures. Furthermore, it did not inhibit FBS stimulated thymidine incorporation. This suggests that the predominate effect of intact IGFBP-5 in the medium is to sequester IGF-I thus inhibiting IGF-I actions and that direct (non-IGF-I dependent) inhibitory effects are a minor component of the response.

All six forms of IGFBPs share structural homology and 
have high affinity for IGF-I and IGF-II. However, each binding protein has unique features including posttranslational modifications, tissue distribution, and the ability to enhance or attenuate IGF actions. IGFBP-5 is abundant in extracellular matrix, where it functions to retain IGFs and enhances their actions $(15,34)$. This property of enhanced ECM binding is relatively specific for IGFBP-5. The experimental data support the conclusion that IGFBP-5 is an important growth regulator for pSMC. The synthesis of IGFBP-5 is stimulated by IGF-I in pSMC, which is not uniformly observed in other cell systems (17). Regulation of pSMC proliferation is correlated with increased production of IGF-I $(4,6,10)$ and IGFBP-5 (12). Since IGFBP-5 regulates IGF-I actions, it is important to determine the consequences of IGFBP-5 degradation. In the present study, we have shown that accumulation of intact IGFBP-5 in medium is inhibitory to IGF-I action on pSMC. This suggests that proteolysis can prevent IGFBP-5 from acting as an inhibitor in medium and suggests that the continued degradation of IGFBP-5 may be required for optimal cellular responsiveness to IGF-I.

In contrast to IGFBP-5 that is present in the interstitial fluid, IGFBP-5 that is sequestered in the extracellular matrix appears to be protected from proteolysis. Furthermore, enrichment of extracellular matrix with IGFBP-5 results in enhanced responsiveness to IGF-I (16). This suggests that proteolysis may indirectly regulate IGF-I actions by limiting the amount of intact high affinity IGFBP-5 in interstitial fluids, therefore, IGFBP-5 proteolysis would also function to cause an increase in the amount of intact IGFBP-5 in the ECM, relative to interstitial fluid. Under these conditions, the primary determinants of IGFBP-5 ECM concentrations would be the amount of available binding sites within the ECM and the rate of IGFBP-5 synthesis. Both proteoglycans (24) and specific ECM proteins such as plasminogen activator inhibitor-1 have been shown to bind to IGFBP-5. However, the factors that regulate the amount of IGFBP-5 that is bound to ECM and what controls their ECM abundance are not well defined. In spite of these gaps in our knowledge, the current study suggests that an important role of proteolysis may be to differentially favor the distribution of IGF-I to its ECM bound form of IGFBP-5. Since this form has an eightfold lower affinity than that in the culture medium, this would favor better equilibration with receptors and long-term maintenance of an enriched amount of IGF-I in the pericellular environment. Other matrices such as bone ECM have been shown to be very rich sources of IGF-II (34). Osteoblasts also produce IGFBP-5 and an IGFBP-5 protease suggesting that the mechanism that we describe for smooth muscle cells may also be operative in this cell type and could function to enhance the accumulation of IGF-II within bone ECM (35). In contrast, other forms of IGFBPs such as IGFBP-4 that do not bind to ECM would not have this pattern of pericellular distribution.

The findings in this study also have important implications for understanding the role of IGF-I in the progression of atherogenesis. IGF-I has been shown to be a potent stimulus of smooth muscle cell protein synthesis, deposition of extracellular matrix, migration, and division. All of these are processes that are important in atherosclerotic lesion development. Extracellular matrix of the vessel wall is a rich source of growth factors such as TGF- $\beta$, basic fibroblasts growth factor, IL-1 $\beta$, and vascular endothelial growth factors (36). It is plausible that IGF-I bound to IGFBP-5 in ECM will play an active role in conjunction with other growth factors at the time of vascular injury and subsequent remodeling. It will be important to determine if smooth muscle cells within atheromatous plaques express the IGFBP-5 protease and if direct infusion of protease-resistant forms of IGFBP-5 into lesions results in attenuation of IGF-I actions. Release of proteases particularly after procedures such as balloon angioplasty are thought to be important for wound repair and early neointima formation (37). Serine proteases such as plasminogen and specific metalloproteases are expressed in vessel walls during remodeling (38). Recently, the crucial role of plasminogen in vascular remodeling was demonstrated using mice deficient in this enzyme. After arterial wall injury, mice lacking plasminogen showed impairment in arterial neointima formation including delayed removal of necrosis debris and decreased migration of smooth muscle cells (39). It is possible that IGFBP-5-specific serine protease functions with other serine proteases in vascular remodeling. Therefore, the significance of this protease in the hierarchy of other serine proteases that are expressed by vessel wall cell types needs further analysis.

\section{Acknowledgments}

The authors wish to thank Ms. Dottie McQueen for her help in preparing the manuscript.

This work was supported by a grant from the National Institutes of Health (HL-56850).

\section{References}

1. Bornfeldt, K.E., E.W. Raines, T. Nakano, L.M. Graves, E.G. Krebs, and R. Ross. 1993. Insulin-like growth factor I and platelet derived growth factorBB induce directed migration of human arterial smooth muscle cells via signaling pathways that are distinct from those of proliferation. J. Clin. Invest. 93: 1266-1274.

2. Bornfeldt, K.E., H.J. Arnqvist, and L. Capron. 1993. In vivo proliferation of rat vascular smooth muscle in relation to diabetes mellitus: insulin-like growth factor I and insulin. Diabetologia. 35:104-108.

3. Clemmons, D.R., and D.S. Shaw. 1983. Variables controlling somatomedin production by cultured human fibroblasts. J. Cell. Physiol. 115:137-143.

4. Khorsondi, M.J., J.A. Fagin, J.C. Ginnella-Neto, J.S. Forrester, and B. Cercek. 1992. Regulation of insulin-like growth factor I and its receptor in rat aorta after balloon degradation: evidence for local bioactivity. J. Clin. Invest. 90:1926-1931.

5. Gockerman, A., J.I. Jones, T. Prevette, and D.R. Clemmons. 1995. Insulin like growth factor binding protein-2 inhibits smooth muscle cell migration response to IGF-I. Endocrinology. 136:4168-4173.

6. Delafontaine, P., H. Lou, and R.W. Alexander. 1991. Regulation of insulin-like growth factor I messenger RNA levels in vascular smooth muscle cells. Hypertension (Dallas). 18:742-747.

7. Padayatty, S.J., S. Orme, P.D. Zenobi, M.H. Strickland, P.E. Belchetz, and P.J. Grant. 1995. The effects of insulin-like growth factor-I on plasminogen activator inhibitor-1 synthesis and secretion: results from in vivo and in vitro studies. Thromb. Hemostasis. 74:1009-1013.

8. King, G.L., A.D. Goodman, S. Buzney, A. Moses, and C.R. Kahn. 1985. Receptors and growth promoting affects of insulin and insulin-like growth factors on cells from bovine retinal capillaries and aorta. J. Clin. Invest. 75:10281036.

9. Delafontaine, P., A. Anwar, H. Lou, and L. Ku. 1996. G-protein coupled and tyrosine kinase receptors: evidence that activation of the insulin-like growth factor I receptor is required for thrombin-induced mitogenesis of rat aortic smooth muscle cells. J. Clin. Invest. 97:139-147.

10. Clemmons, D.R., and J.J. Van Wyk. 1985. Evidence for a functional role of endogenously produced somatomedin-like peptides in the regulation of DNA synthesis in cultured human fibroblasts and porcine smooth muscle cells. J. Clin. Invest. 75:1914-1918.

11. Cohick, W.S., A. Gockerman, and D.R. Clemmons. 1993. Vascular smooth muscle cells synthesize two forms of insulin-like growth factor binding proteins which are regulated differently by the insulin like growth factors. $J$. Cell. Physiol. 157:52-60.

12. Duan, C.M., and D.R. Clemmons. 1996. Insulin like growth factor I (IGF-I) regulates IGF binding protein-5 synthesis through transcriptional acti- 
vation of the gene in aortic smooth muscle cells. J. Biol. Chem. 271:4280-4288.

13. Ross, M., G.L. Francis, L. Szabo, J.C. Wallace, and F.J. Ballard. 1989. Insulin-like growth factor (IGF)-binding proteins inhibit the biological activities of IGF-I and IGF-2 but not des-(1-3)-IGF-I. Biochem. J. 258:267-272.

14. Bourner, M.J., W.H. Busby, N.R. Siegel, G.G. Krivi, R.H. McCusker, and D.R. Clemmons. 1992. Cloning and sequence determination of bovine insulin-like growth factor binding protein-2 (IGFBP-2): comparison of its structural and functional properties with IGFBP-1. J. Cell. Biochem. 48:215-226.

15. Arai, A., W.H. Busby, and D.R. Clemmons. 1996. Binding of insulinlike growth factor I or II to IGF binding protein enables it to bind to heparin or extracellular matrix. Endocrinology. 137:4571-4575.

16. Jones, J.I., A. Gockerman, W.H. Busby, C. Camacho-Hubner, and D.R. Clemmons. 1993. Extracellular matrix contains insulin-like growth factor binding protein-5: potentiation of the effects of IGF-I. J. Cell Biol. 121:679-687.

17. Camacho-Hubner, C., W.H. Busby, R.H. McCusker, G. Wright, and D.R. Clemmons. 1992. Identification of the forms of insulin-like growth factor binding proteins produced by human fibroblasts and the mechanisms that regulate their secretion. J. Biol. Chem. 267:11949-11956.

18. Hunkapiller, M.W., R.M. Hewick, R.J. Dreyer, and L.E. Hood. 1983. High sensitivity sequencing with a gas-phase sequencer. Methods Enyzmol. 91: 399-413.

19. Arai, T., S. Clarke, A. Parker, W.H. Busby, and D.R. Clemmons. 1996. Effect of substitution of specific amino acids in insulin like growth factor binding protein-5 on heparin binding and its change in affinity for IGF-I in response to heparin. J. Biol. Chem. 271:6099-6106.

20. Busby, W.H., D.G. Klapper, and D.R. Clemmons. 1988. Purification of a 31000 dalton insulin-like growth factor binding protein from human amniotic fluid. J. Biol. Chem. 263:14203-14210.

21. Ross, R. 1971. The smooth muscle cell: growth of smooth muscle in cultures and formation of elastic fibers. J. Cell Biol. 50:172-186.

22. Parker, A., A. Gockerman, W.H. Busby, and D.R. Clemmons. 1995. Properties of an insulin like growth factor binding protein 4 protease that is secreted by smooth muscle cells. Endocrinology. 135:2470-2476.

23. Clemmons, D.R. 1985. Exposure to platelet derived growth factor modulates porcine aortic smooth muscle cell response to somatomedin-C. Endocrinology. 117:77-83.

24. Arai, T., A. Arai, W.H. Busby, and D.R. Clemmons. 1994. Glycosaminoglycans inhibit degradation of insulin-like growth factor binding protein-5. Endocrinology. 135:2358-2363.

25. Jones, J.I., T. Prevette, A. Gockerman, and D.R. Clemmons. 1996. Binding of vitronectin to an aVB3 integrin is necessary for smooth muscle cells to migrate in response to IGF-I. Proc. Natl. Acad. Sci. USA. 93:2462-2467.

26. Dong, Y., A. Skoulteki, and J. Pollard. 1993. Efficient DNA transfection of quiescent mammalian cells. Nucleic Acids Res. 21:1771-1772.
27. Nam, T.J., W.H. Busby, and D.R. Clemmons. 1994. Human fibroblasts secrete a serine protease that cleaves insulin like growth factor binding protein-5. Endocrinology. 135:1385-1391.

28. Andress, D.L., and R.S. Birnbaum. 1992. Human osteoblast-derived insulin-like growth factor (IGF) binding protein-5 stimulates osteoblast mitogenesis and potentiates IGF action. J. Biol. Chem. 267:22467-22472.

29. Mohan, S., C.M. Bautista, J. Wergedal, and D.J. Baylink. 1989. Isolation of inhibitory insulin-like growth factor (IGF) binding protein from bone cell conditioned medium: a potential local regulator of IGF action. Proc. Natl. Acad. Sci. USA. 86:8338-8342.

30. Coulouscou, J.M., and M. Shoyab. 1991. Purification of a colon cancer cell growth inhibitor and its identification as insulin-like growth factor binding protein-4. Cancer Res. 51:2813-2819.

31. Schmid, C., J. Rutishauser, I. Schlapfer, E.R. Froesch, and J. Zapf. 1991. Intact but not truncated insulin-like growth factor binding protein-3 blocks IGF-I induced stimulation of osteoblasts: control of IGF signaling to bone cells by IGFBP-3 specific proteolysis. Biochem. Biophys. Res. Commun. 179:579585

32. DeMellow, J.S.M., and R.C. Baxter. 1988. Growth hormone dependent insulin-like growth factor binding protein both inhibits and potentiates IGF-I stimulated DNA synthesis in skin fibroblasts. Biochem. Biophys. Res. Commun. 156:199-204.

33. Reeve, J.G., J. Schwanda, and N.M. Bleecham. 1993. IGFBP-2: an important regulator of insulin like growth factor action in human lung tissues. Growth Regul. 3:82-84.

34. Dollery, C.M., J.R. McEwan, and A.T. Henney. 1995. Matrix metalloproteinases and cardiovascular disease. Circ. Res. 77:8653-8868.

35. Bautista, C.M., D.J. Baylink, and S. Mohan. 1991. Isolation of a novel insulin-like growth factor (IGF) binding protein from human bone: a potential candidate for fixing IGF-II in human bone. Biochem. Biophys. Res. Commun. 176:756-763.

36. Conover, C.A., and M.C. Keifer. 1993. Regulation of biological effect of endogenous insulin like growth factor binding protein 5 in human osteoblas cells. J. Clin. Endocrinol. Metab. 76:1153-1159.

37. Van Leeuwen, R.T.J. 1996. Extracellular proteolysis and the migrating vascular smooth muscle cell. Fibrinoloysis. 10:59-74.

38. Clowes, A.W., M.M. Clowes, Y.P. Au, M.A. Reidy, and D. Belin. 1990 Smooth muscle cells express urokinase during mitogenesis and tissue type plasminogen activator during migration in injured rat carotid artery. Circ. Res. 67: 61-67.

39. Carmeliet, P., L. Moons, V. Plopis, E. Plow, and D. Collen. 1997. Impaired arterial neontima formation in mice with disruption of the plasminogen gene. J. Clin. Invest. 99:200-208. 